\title{
Destructive effects of smoking on molecular and genetic factors of periodontal disease
}

Miki Ojima ${ }^{1}$, Takashi Hanioka ${ }^{2 *}$

\begin{abstract}
Many epidemiological evidences have proven the association between smoking and periodontal disease. The causality can be further established by linking findings of traditional epidemiological studies with the developments in molecular techniques that occurred in the last decade. The present article reviews recent studies that address the effect of smoking on molecular and genetic factors in periodontal disease. Most findings support the fact that tobacco smoking modulates destruction of the periodontium through different pathways: microcirculatory and host immune systems, connective tissue, and bone metabolism. Although smokers experience an increased burden of inflammatory responses to microbial challenges compared to non-smokers, understanding the association between smoking and periodontal diseases involves substantial problems with respect to accuracy of measurements, and particularly, sampling of many subjects. It remains unclear whether genetic susceptibility to periodontal disease is influenced by exposure to smoking or the effect of smoking on periodontal disease is influenced by genetic susceptibility. Employment of molecular techniques may play a key role in further elucidation of mechanisms linking smoking and periodontal destruction, the direct relationship as environmental factors and indirect relationship through genetic factors.
\end{abstract}

\section{Background}

Periodontal disease is defined as inflammatory destruction of periodontal tissue and alveolar bone supporting the teeth. Severe and prolonged periodontal inflammation leads to loss of teeth, thereby affecting oral functions (e.g., mastication, speech, and facial esthetics). Progression and severity of the disease depends on complex interactions between several risk factors such as microbial, immunological, environmental, and genetic factors, as well as age, sex, and race [1]. Tobacco smoking is a significant risk factor for periodontal disease [2].

Epidemiological studies concerning the association between smoking and periodontal disease have markedly increased since the 1990s. Based on epidemiological articles published from 1965 to 2000, the US Surgeon General's Report 2004, which comprehensively addressed active smoking and health issues, concluded that there is sufficient evidence to infer a causal relationship between smoking and periodontal disease [3]. Although biological plausibility is an important criterion in the Bradford-Hill criteria for assigning causality to an

\footnotetext{
*Correspondence: haniokat@college.fdcnet.ac.jp

${ }^{2}$ Department of Preventive and Public Health Dentistry, Fukuoka Dental College, 2-15-1 Tamura, Sawara-ku, Fukuoka 814-0193, Japan
}

association [4], traditional epidemiology correlates exposure with disease outcomes, and everything between the cause and outcome is treated as a "black box" [5].

Despite numerous studies having demonstrated the causal association between smoking and periodontal disease, many questions remain unanswered. For example, what happens when periodontal tissue is exposed to tobacco smoke? How is the onset or progression of periodontal disease in smokers different from that in nonsmokers? The underlying mechanisms of smokingattributed periodontal disease can be further clarified by linking findings of traditional epidemiological studies with those of in vitro studies. Recently, molecular, cellular, and other biological markers (called biomarkers) have been frequently measured in epidemiological studies to reveal the mechanisms and events occurring along the theoretical continuum between exposure to tobacco smoke and the disease.

These biomarkers can be categorized according to the target of qualification, i.e., host responses and genetic factors (Table 1). Host responses can be further grouped as the microcirculatory system, host immune inflammatory response system, and connective tissue and bone metabolism. Since the application of a sampling 
Table 1 Biomarkers employed in studies on smoking and periodontal disease

\begin{tabular}{|c|c|c|}
\hline Target of qualification & Biomarkers & Specimens \\
\hline \multicolumn{3}{|l|}{ Host responses } \\
\hline Microcirculatory system & Microcirculatory functions and intercellular adhesion molecule & Gingival microvasculature \\
\hline $\begin{array}{l}\text { Host immune inflammatory } \\
\text { response systems }\end{array}$ & Immune cells and immunoglobulins & $\begin{array}{l}\text { Blood serum, saliva, gingival crevicular fluid, } \\
\text { and gingival tissue }\end{array}$ \\
\hline $\begin{array}{l}\text { Connective tissue and bone } \\
\text { metabolism }\end{array}$ & Cytokines, prostanoids, and matrix metalloproteinase & \\
\hline Genetic factors & $\begin{array}{l}\text { Genotypes associated with the immune system, inflammation, } \\
\text { and tissue metabolism }\end{array}$ & Blood, buccal swabs, and saliva \\
\hline
\end{tabular}

technique to obtain an informative biomarker is limited, particularly in non-diseased smokers [6], saliva, blood serum, and gingival crevicular fluid (GCF) are used as specimens.

Biological mechanisms of periodontal diseases are characterized by imbalance between bacterial virulence and host defense activity. The most plausible mechanism that explains the relationship between smoking and periodontal disease is that smoking, an environmental factor, interacts with host cells and affects inflammatory responses to microbial challenge [7]. Alternatively, the toxic components of tobacco smoke, e.g., nicotine, may directly or indirectly deteriorate periodontal tissue. Recently, genetic susceptibility to periodontal disease has been receiving much attention with respect to smoking-periodontal disease relationships. This review describes smoking as an environmental factor of periodontal disease and the interrelationship between smoking and genetic factors in periodontal disease in studies using molecular biology techniques.

\section{Search strategy}

The PubMed database was examined for English language publications from 1965 to 2008, using the following key words: "smoking," "smokers," "tobacco," "periodontal diseases," and "periodontitis." These terms were mainly searched as title words. Epidemiological studies not employing biological measurements and review articles were excluded. Most of the articles were published in the last 10-15 years. Consequently, 134 studies were evaluated and 60 have been included in this review.

\section{Inflammatory host responses Microcirculatory System}

Changes in vascular formations and microcirculatory functions in periodontal tissue following smoking can influence immune function and the subsequent inflammatory reaction in the gingiva. A significantly smaller number of vessels were observed in the inflamed gingival tissues of smokers compared to non-smokers [8]. Continuous smoking has a long-term effect that impairs the vasculature of periodontal tissue. Acute exposure to cigarette smoke induces gingival hyperemia, which is caused by the concomitant increase in blood pressure against a small but significant sympathetically induced vasoconstriction in healthy gingiva [9]. Smoking even one cigarette may cause a decrease in gingival blood flow and vascular conductance [10]. Small repeated vasoconstrictive attacks and impairment of revascularization due to cigarette smoking may contribute to disruption of the immune response and delay in the healing response, leading to an increased risk of periodontal disease. Gingival blood flow in periodontally healthy regular smokers significantly increased three days after quitting, and further small increases occurred until eight weeks compared to the baseline [11].

Vascular dysfunction may be related to impairment of oxygen delivery to gingival tissue. Smokers exhibited lower function of oxygen sufficiency in healthy gingiva and reduced ability to adapt to the function in inflamed gingiva, compared to non-smokers [12]. Pocket oxygen tension was significantly lower in smokers than in nonsmokers, possibly due to impaired microcirculatory function. Correlation of pocket oxygen tension to gingival oxygen saturation of hemoglobin was highly significant in non-smokers, but this association was absent in smokers [13].

Smoking-induced endothelial dysfunction may lead to inflammatory activation within the vascular wall, mediated by cytokines and adhesion molecules. Intercellular adhesion molecule-1 (ICAM-1) is expressed on the cell surface of the endothelium of the gingival vasculature and in the junctional epithelium; it is critical in leukocyte trafficking through gingival tissue. The level of soluble ICAM-1 (sICAM-1) was higher in smokers than in age-matched non-smoking controls [14]. The mean serum sICAM-1 concentration was elevated in smokers compared to non-smokers. Conversely, the mean concentration of sICAM-1 in GCF of subjects with periodontitis was significantly lower in smokers than in nonsmokers [15].

\section{Host Immune System}

The number of neutrophils in GCF was lower or remained constant in smokers compared to non- 
smokers [16]. However, smoking can affect neutrophil increase in blood in a dose-dependent manner [17]. Deleterious effects of smoking on the function of polymorphonuclear neutrophils, including reduced viability and phagocytosis, were observed in periodontally healthy smokers, in a dose-response manner [18]. Although there are some conflicting data, smoking may alter neutrophil behavior in periodontal tissue. It is reported that lung macrophages are functionally compromised, e.g., reduction in capacity to produce cytokines and phagocytize microorganisms [19].

Limited evidence suggests that smoking may influence lymphocyte numbers and antibody production. In a previous study, smoking was significantly associated with an increased number of $\mathrm{CD} 3+$ and $\mathrm{CD} 4+\mathrm{T}$ cells with a clear dose-response effect, whereas CD19+ B cells were not affected by smoking [20]. The CD4+ and CD8+ T cell values after periodontal treatment were lower in smokers than in non-smokers [21]. The serum level of IgG (Immunoglobulin G), particularly IgG2, which is an important antibody against gram-negative periodontal pathogens, was decreased in periodontitis patients who were smokers [22-27]. These findings suggest that smoking decreases the proliferative capacity of $\mathrm{T}$ cells or T-cell-dependent antibody responses that affect Bcell function and antibody generation.

\section{Connective Tissue and Bone Metabolism}

Among several cytokines, levels of interleukin (IL)-1 in GCF have been extensively compared between smokers and non-smokers. Smokers exhibited significantly lower concentrations of IL-1 $\alpha$ and IL-1ra in GCF than nonsmokers $[16,28]$. The GCF level of IL- $1 \beta$ at deep bleeding sites was lower in smokers than in non-smokers [29]. This level was not different between smokers and non-smokers prior to periodontal therapy; however, it was significantly higher in smokers than in non-smokers at diseased sites following therapy [25]. Healthy smokers exhibited higher total amounts of IL- $1 \beta$ in GCF than non-smokers [30]. Serum IL-1 $\beta$ in patients with untreated aggressive periodontitis showed a positive correlation with smoking [31].

Other ILs, such as IL-4, IL-6, IL-8, and IL-10, and tumor necrosis factor- $\alpha$ (TNF- $\alpha$ ) have also been investigated. The total amount of IL-4 in GCF was lower in smokers than in non-smokers and remained stable in smokers but decreased in non-smokers during induction of experimental gingivitis [32]. Smokers with early onset periodontitis exhibited lower levels of IL-4 in GCF than non-smokers [33]. The total amount of IL-10 in GCF at diseased sites was significantly lower in smokers than in non-smokers [25]; however, the levels of IL-6 and IL-8 in GCF were higher in smokers than in non-smokers $[32,33]$. Smokers exhibited a significantly higher level of
TNF- $\alpha$ than non-smokers, though smoking was not associated with levels of IL-1 $\beta$, IL-1ra, and IL- 6 in GCF $[34,35]$.

Considering these findings, smokers tend to exhibit excess production of inflammatory molecules, such as IL-6, IL-8, and TNF- $\alpha$, and suppression of anti-inflammatory molecules, such as IL-4, IL-10, and IL-1ra; however, these findings are partly inconsistent.

IL-8 can attract and activate neutrophils. Findings regarding the effects of smoking on the level of neutrophil-derived proteolytic enzymes in oral specimens are inconsistent; however, smoking may increase their level in systemic circulation. Smokers had significantly higher elastase concentrations in GCF than non-smokers, regardless of pocket depths [36,37], while elastase concentrations decreased in smokers compared to nonsmokers [38] and former smokers [18]. Plasma matrix metalloproteinase-9 (MMP-9) of smokers was 6.45 times higher than that of non-smokers [39]. Smoking was highly correlated with the MMP-3 level in GCF [40]. MMP-8 expression in periodontal tissue was significantly higher in smokers than in non-smokers [41], while the salivary MMP-8 level was significantly lower in current smokers than in former smokers [42]. Smoking may suppress the activities of protease inhibitors. Smokers had a significantly lower concentration of $\alpha-2$ macroglobulin in GCF as well as total amounts of $\alpha-2$ macroglobulin and $\alpha$-1-antitrypsin than non-smokers [43]. Smoking seems to disturb the balance between proteolytic and anti-proteolytic activities in periodontal tissue.

IL-1, IL-6, and TNF- $\alpha$ stimulate the expression of the receptor activator of nuclear factor- $\kappa \beta$ ligand (RANKL) and the inhibitor protein osteoprotegerin (OPG), which are essential factors for bone resorption and remodeling. Smoking did not affect the mean levels of free soluble RANKL (sRANKL) in GCF [44]. The OPG concentration was significantly lower and the sRANKL/OPG ratio was higher in smokers than in non-smokers, in saliva [45] as well as serum [46], explaining the greater potential for bone loss in smokers.

IL-1 and IL-6 induce production of prostaglandin $\mathrm{E}_{2}$ $\left(\mathrm{PGE}_{2}\right)$ by neutrophils and macrophages, which could also promote periodontal bone resorption. However, the level of $\mathrm{PGE}_{2}$ in GCF in smokers was similar to that in non-smokers $[47,48]$ or even lower than that in nonsmokers $[49,36]$. The level of salivary $\mathrm{PGE}_{2}$ was also lower in smokers than in non-smokers [50]. Interference of prostaglandin production may be related to the vasoconstricting effect of smoking [51] (refer Microcirculatory system).

The level of free oxygen radicals in periodontal tissues was increased in smokers compared to non-smokers [52]. Oxidative stress induces tissue damage by injuring 
cells such as fibroblasts. Tobacco products inhibit attachment and growth of fibroblasts derived from human periodontal ligaments [53]. Fibroblasts impaired by smoking possibly lead to delay in tissue repair and wound healing in periodontal disease.

Smoking-associated pathophysiological changes in periodontal tissue evaluated by biological measurements are summarized in Table 2. Reduction in GCF observed in smokers may influence the conflicting results between the levels of several biomarkers in GCF and blood. It remains unclear whether these changes are due to nicotine or other components of tobacco smoke and systemic or local effects of smoking. The common mechanism in periodontal and systemic disease under the influence of smoking may be revealed by markers for inflammatory responses, tissue damage, and vascular effects [54].

\section{Genetic factors}

Gene polymorphisms have been investigated as possible markers of increased susceptibility to periodontal diseases: IL-1, IL-4, IL-10; TNF- $\alpha$; Fc $\gamma$ receptor; human leukocyte antigen; vitamin $\mathrm{D}$ receptor; and $\mathrm{N}$-formyl peptide receptor [55]. Relationships between smoking and genetic susceptibility to periodontal diseases have been strengthened with respect to genotypes associated with cytokines (IL-1, IL-6, and IL-10), the immune system (Fc $\gamma$ receptor), bone metabolism (vitamin D receptor), and xenobiotics metabolism ( $\mathrm{N}$-acetyltransferase and myeloperoxidase). These studies have been listed in Table 3.
IL-1 polymorphisms have been intensively studied using a cross-sectional approach, except for one study that employed a longitudinal design [56]. The relationship with respect to smoking is controversial. The association between positive genotypes and the severity of periodontal disease was independent of smoking $[57,58]$, suggesting no relationship between smoking and IL-1 genotypes; however, relationships between IL-1-positive genotypes and smoking was evident [59-63]. Logistic regression analysis of periodontal disease with genotype-negative non-smokers as a reference group exhibited odds ratios of 0.98 for genotypepositive non-smokers, 2.37 for genotype-negative smokers, and 4.50 for genotype-positive smokers, thus suggesting synergism between IL-1 polymorphism and smoking [64].

Non-smokers with moderate periodontitis and periodontally healthy subjects displayed a higher incidence of IL-6 G-genotype than severe periodontitis subjects [65]. The difference in the occurrence of the IL-10 GG genotype between severe chronic periodontitis and control groups was more evident in non-smokers [66]. Gene coding for the ligand-binding chain of interferon gamma receptor 1 , a cytokine that plays a pivotal role in defense against infection, was significantly associated with periodontitis in combination with smoking [67]. IgG-binding factors, namely Fc $\gamma$ receptors, could influence the ability of phagocytosis. Genotypes of Fc $\gamma$ receptor, Fc $\gamma$ RIIa, and Fc $\gamma$ RIIIb, may be associated with periodontal disease in smokers [68,69]. Vitamin D receptor Taq-I TT polymorphism was moderately

Table 2 Pathophysiological changes associated with smoking

\begin{tabular}{|c|c|c|}
\hline Target of qualification & Biomarkers* & Articles \\
\hline Microcirculatory system & $\begin{array}{l}\text { Gingival blood flow (chronic effect } \downarrow \text { and acute effect } \uparrow \text {, quit effect } \uparrow \text { ) } \\
\text { Number of vessels in inflamed site } \downarrow \text { (Gingival bleeding } \downarrow \text { ) } \\
\text { Oxygen sufficiency } \downarrow \\
\text { Pocket oxygen tension } \downarrow \\
\text { sICAM- } 1 \text { ? (Serum } \uparrow \text { and GCF } \downarrow \text { ) }\end{array}$ & $\begin{array}{l}9-11 \\
8 \\
12 \\
13 \\
14,15\end{array}$ \\
\hline Host immune inflammatory response systems & $\begin{array}{l}\text { PMNs or neutrophil count ? (blood } \uparrow \text { and GCF } \downarrow \text { ) } \\
\text { PMN function (chemotaxis, phagocytosis, and oxidative burst) } \downarrow \\
\text { Macrophage function } \downarrow \\
\text { T lymphocytes? } \\
\text { lgG2 } \downarrow\end{array}$ & $\begin{array}{l}16,17 \\
18 \\
19 * \\
17,20,21 \\
22-27\end{array}$ \\
\hline Connective tissue and bone metabolism & $\begin{array}{l}\text { IL-1a/ } \beta \text { and IL-1ra } \downarrow \\
\text { IL-6 and IL-8 } \uparrow, I L-4 \text {, and IL-10 } \downarrow \text {,TNF- } \alpha \uparrow \\
\text { Elastase activity? } \\
\text { MMP-9 and MMP-3 in GCF } \uparrow \\
\text { MMP-8? (GCF } \uparrow \text { and saliva } \downarrow \text { ) } \\
\alpha-2-M a c r o g l o b u l i n \\
\downarrow \text { OPG } \downarrow \text { and sRANKL/OPG ratio } \uparrow \\
\text { Prostaglandin } E_{2} \downarrow \\
\text { Free radicals } \uparrow \\
\text { Gingival fibroblast } \downarrow \text { (Tissue repair and wound healing } \downarrow \text { ) }\end{array}$ & $\begin{array}{l}16,25,28-31 \\
25,32-35 \\
18,36-38 \\
39,40 \\
41,42 \\
43 \\
44-46 \\
36,47-50 \\
52 \\
53\end{array}$ \\
\hline
\end{tabular}

${ }^{*} \uparrow$ : increase, $\downarrow$ : decrease, ?: uncertain. ${ }^{* *}$ Lung macrophages

ICAM-1: intercellular adhesion molecule-1, GCF: gingival crevicular fluid, PMN: polymorphonuclear neutrophil, IgG: immunoglobulin G, IL: interleukin, TNF- $\alpha$ : tumor necrosis factor- $\alpha$, MMP: matrix metalloproteinase, OPG: osteoprotegerin, RANKL: receptor activator of nuclear factor- $\kappa \beta$ ligand 
Table 3 Target genotypes and study population in association with periodontal disease and smoking

\begin{tabular}{ll}
\hline Genotypes & Subjects \\
\hline IL-1A -889, IL-1B & 134 subjects, USA \\
+3954 (originally & \\
described as +3953) & \\
IL-1A -889, IL-1B & 28 African-American and 7 Caucasian-American \\
+3954 (originally & families (early onset periodontitis affected and \\
described as +3953) & unaffected subjects), USA \\
IL-1A -889 & 46 patients and 12 controls, UK
\end{tabular}

\begin{tabular}{ll} 
Main findings & Articles \\
\hline The polymorphic IL-1 gene cluster was associated with & 59
\end{tabular}

severity of periodontitis only in non-smokers.

IL-1ß disequilibrium with EOP was found both in smokers and 57 non-smokers.

The carriage of allele 2 was associated with an increase in IL-I 28 $\alpha$ protein levels, especially in non-smokers, while heavy smokers showed reduced levels of IL-| $\alpha$ protein, regardless of genotype.

IL-1A -4845, IL-1B 295 Caucasians, Australia

A relationship was observed between the IL-1-positive genotype and increased mean probing pocket depth in nonsmokers more than 50 years of age. IL-1 genotype-positive smokers had an increase in the number of probing depths $\geq 3.5 \mathrm{~mm}$.

IL-1A +4845, IL-B 90 patients (non- or former smokers), USA $+3954$

IL-1 genotype-positive non-smokers or former light smokers were at increased odds of having moderate-to-severe periodontal disease compared to IL-1 genotype-negative patients. The presence of both former moderate smoking history and IL-1-positive genotype showed a lower likelihood of developing the disease when compared to those with presence of only one of the risk factors.

IL-1A -889, IL-1B 154 Caucasians, Germany

Severity of periodontitis was associated with the composite genotype of IL-1 $\alpha / 1 \beta$ in smokers, while no differences were found in genotype-negative subjects, irrespective of their smoking status.

\begin{tabular}{|c|c|}
\hline $\begin{array}{l}\text { IL-1A -889, IL-1B } \\
+3954, \text { IL-1B }-511\end{array}$ & 1085 Caucasians, Germany \\
\hline IL-1A -889 IL-1B +3954 & 330 patients and 101 controls, Chile \\
\hline IL $-6-174$ & 155 patients and 54 controls, Brazil \\
\hline IL-10 -1087 & 60 patients and 39 controls, Sweden \\
\hline $\begin{array}{l}\text { Vitamin D receptor } \\
\text {-1056 Taq-I }\end{array}$ & 303 patients and 231 controls, UK \\
\hline FcyRlllb & 164 subjects aged 70 years old, Japan \\
\hline FcyRlla & 422 Caucasians, USA \\
\hline $\begin{array}{l}\text { FcyRllla -158V/F, } \\
\text { FcyRlllb -NA1/NA2 }\end{array}$ & 1083 Caucasians, Germany \\
\hline IFNGR1 & 62 patients and 56 controls, Norway \\
\hline $\begin{array}{l}\text { NAT2 -T341C, -G590A, } \\
\text { G857A MPO G-463a }\end{array}$ & 1083 Caucasians, Germany \\
\hline
\end{tabular}

An increased risk of periodontal disease and tooth loss was observed for IL-1 genotype-positive smokers.

The association between positive genotype and periodontitis was independent of smoking status.

An association between the G-genotype and periodontal status was observed only in non-smokers.

An association between the GG genotype and periodontal status was more conspicuous in non-smokers.

Vitamin D receptor Taq-I TT polymorphism was moderately 70 associated with both the presence and progression of periodontitis in smokers.

An association between smoking and periodontal disease progression in elderly people with FcyRlllb-NA2 polymorphism.

FcyRlla-H/H131 genotype may be associated with chronic periodontitis risk in smokers.

Smokers show a significantly increased attachment loss in the presence of FcyRlllb-NA2 allele. The different genotypes show no differences in non-smokers.

In combination with smoking, IFNGR1 was significantly associated with periodontitis. at an increased risk of periodontitis.

IL: interleukin, FcrR: Fcy receptor, IFNGR1: interferon gamma receptor 1, NAT: N-acetyltransferase, MPO: myeloperoxidase

associated with both the presence and progression of periodontitis in smokers [70]. Gene polymorphisms for enzymes that can metabolize smoking-derived substances may contribute to individual susceptibility to the risk of periodontitis among smokers. Subjects with the polymorphic cytochrome P450 1A1 M2 allele and glutathione S-transferase M1 allele exhibited an increased risk of periodontitis [71].

\section{Conclusions}

The process of periodontal disease is such that a microbial challenge induces a host response, which may result in connective tissue and alveolar bone destruction. Most findings support that smoking modulates the destruction of the periodontium through different pathways: microcirculatory and host immune systems, connective tissue, and bone metabolism. Although smokers exhibit an 
increased burden of inflammatory responses to microbial challenges compared to non-smokers, substantial problems still persists with respect to the accuracy of measurements, and particularly, the sampling of many subjects. Limited evidences are available regarding the effects of quitting smoking on pathophysiological changes in periodontal tissue.

At present, gene-smoking relationships in periodontal disease are suggestive. The reported gene-smoking relationships in periodontal disease should be carefully interpreted in two ways. First is the uncertainty of the relationship because of methodological limitations such as employment of subjects in a specific race, small sample size, and lack of detailed history of smoking and possible confounders. Further studies with adequate statistical power and small biases would be required to clarify the relationship. Furthermore, it remains unclear whether genetic susceptibility to periodontal disease is influenced by exposure to smoking or the effect of smoking on periodontal disease is influenced by genetic susceptibility. The second issue is an ethical problem. If a smoker with positive genotypes associated with inflammatory cytokines is proven to be at a high risk of periodontal disease, the evidence is so strong that the smoker should be encouraged to quit smoking. In contrast, however, the evidence may cause a smoker with negative genotypes to avoid quitting smoking, thereby causing fatal diseases. Within such limitations, geneenvironment relationship studies possibly provide valuable insights into the pathogenesis of complex periodontal diseases and are expected to contribute to prevent the disease through personalized recommendation and targeted intervention in dental public and clinical programs.

Employment of molecular techniques may play a key role in further elucidation of mechanisms linking smoking and periodontal destruction, the direct relationship as environmental factors and indirect relationship through genetic factors.

\section{Acknowledgements}

TH is supported by a Grant-in-Aid for Cancer Research (17-1), Health and Labor Sciences Research Grants for Clinical Cancer Research (H19-010), Comprehensive Research on Cardiovascular and Life-Style Related Diseases (H19-007) from the Ministry of Health, Labor, and Welfare, Japan, and Grantin-Aid for Exploratory Research from the Japan Society for the Promotion of Science.

\section{Author details}

${ }^{1}$ Department of Preventive Dentistry, Graduate School of Dentistry, Osaka University, 1-8 Yamadaoka, Suita, Osaka 565-0871, Japan. ²Department of Preventive and Public Health Dentistry, Fukuoka Dental College, 2-15-1 Tamura, Sawara-ku, Fukuoka 814-0193, Japan.

\section{Authors' contributions}

$\mathrm{MO}$ evaluated the literature and drafted the manuscript. TH conceived the idea for the review and helped draft the manuscript. Both authors participated in the design and coordination of the review. They also read and approved the final version of the manuscript.

\section{Competing interests}

The authors declare that they have no competing interests.

Received: 17 October 2009

Accepted: 20 February 2010 Published: 20 February 2010

\section{References}

1. Nunn ME: Understanding the etiology of periodontitis: an overview of periodontal risk factors. Periodontol 2000 2003, 32:11-23.

2. Mullally $\mathrm{BH}$ : The influence of tobacco smoking on the onset of periodontitis in young persons. Tob Induc Dis 2004, 2:53-65.

3. US Department of Health and Human Services: Dental diseases. The Health Consequences of Smoking. A Report of the Surgeon General Washington DC: US Department of Health and Human ServicesSamet JM, Norman LA, Wilbanks C 2004, 732-766.

4. Hill $A B$ : The environment and disease: association or causation?. Proc $R$ Soc Med 1965, 58:295-300.

5. Schulte PA: Molecular Epidemiology: Principles and Practices. San Diego Academic Press 1993.

6. Shield PG: Molecular epidemiology of smoking and lung cancer. Oncogene 2002, 21:6870-6876.

7. Palmer RM, Wilson RF, Hasan AS, Scott DA: Mechanisms of action of environmental factors-tobacco smoking. J Clin Periodontol 2005, 32:180-195.

8. Rezavandi K, Palmer RM, Odell EW, Scott DA, Wilson RF: Expression of ICAM-1 and E-selectin in gingival tissues of smokers and non-smokers with periodontitis. J Oral Pathol Med 2002, 31:59-64.

9. Mavropoulos A, Aars H, Brodin P: Hyperaemic response to cigarette smoking in healthy gingiva. J Clin Periodontol 2003, 30:214-221.

10. Mavropoulos A, Brodin P, Rosing CK, Aass AM, Aars H: Gingival blood flow in periodontitis patients before and after periodontal surgery assessed in smokers and non-smokers. J Periodontol 2007, 78:1774-1782.

11. Morozumi T, Kubota T, Sato T, Okuda K, Yoshie H: Smoking cessation increases gingival blood flow and gingival crevicular fluid. J Clin Periodontol 2004, 31:267-272.

12. Hanioka T, Tanaka M, Ojima M, Takaya K, Matsumori Y, Shizukuishi S: Oxygen sufficiency in the gingiva of smokers and non-smokers with periodontal disease. J Periodontol 2000, 71:1846-1851.

13. Hanioka T, Tanaka M, Takaya K, Matsumori Y, Shizukuishi S: Pocket oxygen tension in smokers and non-smokers with periodontal disease. $J$ Periodontol 2000, 71:550-554.

14. Koundouros E, Odell E, Coward P, Wilson R, Palmer RM: Soluble adhesion molecules in serum of smokers and non-smokers, with and without periodontitis. J Periodontal Res 1996, 31:596-599.

15. Fraser HS, Palmer RM, Wilson RF, Coward PY, Scott DA: Elevated systemic concentrations of soluble ICAM-1 (sICAM) are not reflected in the gingival crevicular fluid of smokers with periodontitis. J Dent Res 2001, 80:1643-1647.

16. Petropoulos G, McKay IJ, Hughes FJ: The association between neutrophil numbers and interleukin-1alpha concentrations in gingival crevicular fluid of smokers and non-smokers with periodontal disease. J Clin Periodontol 2004, 31:390-395.

17. Loos BG, Roos MTL, Schellekens PTA, Velden van der U, Miedema F: Lymphocyte numbers and function in relation to periodontitis and smoking. J Periodontol 2004, 75:557-564.

18. Guntsch A, Erler M, Preshaw PM, Sigusch BW, Klinger G, Glockmann E: Effect of smoking on crevicular polymorphonuclear neutrophil function in periodontally healthy subjects. J Periodontal Res 2006, 41:184-188.

19. Barbour SE, Nakashima K, Zhang JB, Tangada S, Hahn CL, Schenkein HA, Tew JG: Tobacco and smoking: environmental factors that modify the host response (immune system) and have an impact on periodontal health. Crit Rev Oral Biol Med 1997, 8:437-60.

20. Pauletto NC, Liede K, Nieminen A, Larjava H, Uitto VJ: Effect of cigarette smoking on oral elastase activity in adult periodontitis patients. $J$ Periodontol 2000, 71:58-62.

21. Orbak R, Erciyas K, Kaya H: Flow-cytometric analysis of T-lymphocyte subsets after different treatment methods in smokers and non-smokers with chronic periodontitis. Int Dent J 2003, 53:159-164. 
22. Quinn SM, Zhang JB, Gunsolley JC, Schenkein HA, Tew JG: The influence of smoking and race on adult periodontitis and serum lgG2 levels. J Periodontol 1998, 69:171-177.

23. Califano JV, Schifferle RE, Gunsolley JC, Best AM, Schenkein HA, Tew JG: Antibody reactive with Porphyromonas gingivalis serotypes K1-6 in adult and generalized early-onset periodontitis. J Periodontol 1999, 70:730-735.

24. Graswinckel JE, Velden van der U, van Winkelhoff AJ, Hoek FJ, Loos BG: Plasma antibody levels in periodontitis patients and controls. J Clin Periodontol 2004, 31:562-568.

25. Goutoudi P, Diza E, Arvanitidou M: Effect of periodontal therapy on crevicular fluid interleukin-1beta and interleukin-10 levels in chronic periodontitis. J Dent 2004, 32:511-520.

26. Al-Ghamdi HS, Anil S: Serum antibody levels in smoker and non-smoker saudi subjects with chronic periodontitis. J Periodontol 2007, 78:1043-1050.

27. Gunsolley JC, Pandey JP, Quinn SM, Tew J, Schenkein HA: The effect of race, smoking and immunoglobulin allotypes on lgG subclass concentrations. J Periodontal Res 1997, 32:381-387.

28. Shirodaria S, Smith J, McKay IJ, Kennett CN, Hughes FJ: Polymorphisms in the IL-1A gene are correlated with levels of interleukin-1alpha protein in gingival crevicular fluid of teeth with severe periodontal disease. J Dent Res 2000, 79:1864-1869.

29. Rawlinson A, Grummitt JM, Walsh TF, lan Douglas CW: Interleukin 1 and receptor antagonist levels in gingival crevicular fluid in heavy smokers versus non-smokers. J Clin Periodontol 2003, 30:42-48.

30. Kamma JJ, Giannopoulou C, Vasdekis VGS, Mombelli A: Cytokine profile in gingival crevicular fluid of aggressive periodontitis: influence of smoking and stress. J Clin Periodontol 2004, 31:894-902.

31. Mengel R, Bacher M, Flores-De-Jacoby L: Interactions between stress, interleukin-1beta, interleukin- 6 and cortisol in periodontally diseased patients. J Clin Periodontol 2002, 29:1012-1022.

32. Giannopoulou C, Cappuyns I, Mombelli A: Effect of smoking on gingival crevicular fluid cytokine profile during experimental gingivitis. J Clin Periodontol 2003, 30:996-1002.

33. Giannopoulou C, Kamma JJ, Mombelli A: Effect of inflammation, smoking and stress on gingival crevicular fluid cytokine level. J Clin Periodontol 2003, 30:145-153.

34. Boström L, Linder LE, Bergström J: Clinical expression of TNF-alpha in smoking-associated periodontal disease. J Clin Periodontol 1998, 25:767-773.

35. Boström L, Linder LE, Bergström J: Smoking and crevicular fluid levels of IL-6 and TNF-alpha in periodontal disease. J Clin Periodontol 1999, 26:352-357.

36. Söder B, Jin $L$, Wickholm S: Granulocyte elastase, matrix metalloproteinase-8 and prostaglandin E2 in gingival crevicular fluid in matched clinical sites in smokers and non-smokers with persistent periodontitis. J Clin Periodontol 2002, 29:384-391.

37. Söder B: Neutrophil elastase activity, levels of prostaglandin E2, and matrix metalloproteinase- 8 in refractory periodontitis sites in smokers and non-smokers. Acta Odontol Scand 1999, 57:77-82.

38. Alavi AL, Palmer RM, Odell EW, Coward PY, Wilson RF: Elastase in gingival crevicular fluid from smokers and non-smokers with chronic inflammatory periodontal disease. Oral Dis 1995, 1:110-114.

39. Söder B, Airila MS, Söder PO, Kari K, Meurman J: Levels of matrix metalloproteinases- 8 and -9 with simultaneous presence of periodontal pathogens in gingival crevicular fluid as well as matrix metalloproteinase-9 and cholesterol in blood. J Periodontal Res 2006 41:411-417.

40. Alpagot T, Bell C, Lundergan W, Chambers DW, Rudin R: Longitudinal evaluation of GCF MMP-3 and TIMP-1 levels as prognostic factors for progression of periodontitis. J Clin Periodontol 2001, 28:353-359.

41. Liu KZ, Hynes A, Man A, Alsagheer A, Singer DL, Scott DA: Increased local matrix metalloproteinase- 8 expression in the periodontal connective tissues of smokers with periodontal disease. Biochim Biophys Acta 2006, 1762:775-780.

42. Liede KE, Haukka JK, Hietanen JH, Mattila MH, Ronka H, Sorsa T: The association between smoking cessation and periodontal status and salivary proteinase levels. J Periodontol 1999, 70:1361-1368.
43. Persson L, Bergström J, Ito H, Gustafsson A: Tobacco smoking and neutrophil activity in patients with periodontal disease. J Periodontol 2001, 72:90-95

44. Sakellari D, Menti $S$, Konstantinidis A: Free soluble receptor activator of nuclear factor-kappab ligand in gingival crevicular fluid correlates with distinct pathogens in periodontitis patients. J Clin Periodontol 2008, 35:938-943.

45. Buduneli N, Biyikoglu B, Sherrabeh S, Lappin DF: Saliva concentrations of RANKL and osteoprotegerin in smoker versus non-smoker chronic periodontitis patients. J Clin Periodontol 2008, 35:846-852.

46. Lappin DF, Sherrabeh S, Jenkins WMM, Macpherson LMD: Effect of smoking on serum RANKL and OPG in sex, age and clinically matched supportive-therapy periodontitis patients. J Clin Periodontol 2007, 34:271-277.

47. Preshaw PM, Lauffart B, Zak E, Jeffcoat MK, Barton I, Heasman PA: Progression and treatment of chronic adult periodontitis. J Periodontol 1999, 70:1209-1220.

48. Heasman PA, Lauffart BL, Preshaw PM: Crevicular fluid prostaglandin $E_{2}$ levels in periodontitis-resistant and periodontitis-susceptible adults. $J$ Clin Periodontol 1998, 25:1003-1007.

49. Zhong Y, Slade GD, Beck JD, Offenbacher S: Gingival crevicular fluid interleukin-1beta, prostaglandin E2 and periodontal status in a community population. J Clin Periodontol 2007, 34:285-293.

50. Kibayashi M, Tanaka M, Nishida N, Kuboniwa M, Kataoka K, Nagata H, Nakayama K, Morimoto K, Shizukuishi S: Longitudinal study of the association between smoking as a periodontitis risk and salivary biomarkers related to periodontitis. J Periodontol 2007, 78:859-867.

51. Goodfield MJD, Hume A, Rowell NR: The acute effects of cigarette smoking on cutaneous blood flow in smoking and nonsmoking subjects with and without Raynaud's phenomenon. Br J Rheumatol 1990, 29:89-91.

52. Garg N, Singh R, Dixit J, Jain A, Tewari V: Levels of lipid peroxides and antioxidants in smokers and nonsmokers. J Periodontal Res 2006, 41:405-410.

53. James JA, Sayers NM, Drucker DB, Hull PS: Effects of tobacco products on the attachment and growth of periodontal ligament fibroblasts. $J$ Periodontol 1999, 70:518-25.

54. Berlin I: Smoking-induced metabolic disorders: a review. Diabetes Metab 2008, 34:307-314.

55. Meng H, Xu L, Li Q, Han J, Zhao Y: Determinants of host susceptibility in aggressive periodontitis. Periodontol 2000 2007, 43:133-159.

56. Cullinan MP, Westerman B, Hamlet SM, Palmer JE, Faddy MJ, Lang NP, Seymour GJ: A longitudinal study of interleukin-1 gene polymorphisms and periodontal disease in a general adult population. J Clin Periodontol 2001, 28:1137-1144.

57. Diehl SR, Wang Y, Brooks CN, Burmeister JA, Califano JV, Wang S, Schenkein HA: Linkage disequilibrium of interleukin-1 genetic polymorphisms with early-onset periodontitis. J Periodonto/ 1999, 70:418-430.

58. Lopéz NJ, Jara L, Valenzuela CY: Association of interleukin-1 polymorphisms with periodontal disease. J Periodontol 2005, 76:234-243.

59. Kornman KS, Crane A, Wang HY, di Giovine FS, Newman MG, Pirk FW, Wilson TG Jr, Higginbottom FL, Duff GW: The interleukin-1 genotype as a severity factor in adult periodontal disease. J Clin Periodontol 1997, 24:72-77.

60. McDevitt MJ, Wang HY, Knobelman C, Newman MG, di Giovine FS, Timms J, Duff GW, Kornman KS: Interleukin-1 genetic association with periodontitis in clinical practice. J Periodonto/ 2000, 71:156-163.

61. Meisel P, Siegemund A, Grimm R, Herrmann FH, John U, Schwahn C, Kocher T: The interleukin-1 polymorphism, smoking, and the risk of periodontal disease in the population-based SHIP study. J Dent Res 2003, 82:189-193.

62. Meisel P, Siegemund A, Dombrowa S, Sawaf H, Fanghaenel J, Kocher T: Smoking and polymorphisms of the interleukin-1 gene cluster (IL1alpha, IL-1beta, and IL-1RN) in patients with periodontal disease. J Periodontol 2002, 73:27-32.

63. Meisel P, Heins G, Carlsson L, Giebel J, John U, Schwahn C, Kocher T: Impact of genetic polymorphisms on the smoking-related risk of periodontal disease: the population-based study SHIP. Tob Induc Dis 2003, 1:197. 
64. Meisel P, Schwahn C, Gesch D, Bernhardt O, John U, Kocher T: Dose-effect relation of smoking and the interleukin-1 gene polymorphism in periodontal disease. J Periodontol 2004, 75:236-242.

65. Moreira PR, Lima PM, Sathler KO, Imanishi SA, Costa JE, Gomes RS, Gollob K, Dutra WO: Interleukin-6 expression and gene polymorphism are associated with severity of periodontal disease in a sample of Brazilian individuals. Clin Exp Immunol 2007, 148:119-126.

66. Berglundh T, Donati M, Hahn-Zoric M, Hanson LA, Padyukov L: Association of the -1087 IL 10 gene polymorphism with severe chronic periodontitis in Swedish Caucasians. J Clin Periodontol 2003, 249-254.

67. Fraser DA, Loos BG, Boman U, van Winkelhoff AJ, Velden van der U,

Schenck K, Dembic Z: Polymorphisms in an interferon-gamma receptor-1 gene marker and susceptibility to periodontitis. Acta Odontol Scand 2003, 61:297-302.

68. Yoshihara A, Sugita N, Yamamoto K, Kobayashi T, Hirotomi T, Ogawa H, Miyazaki H, Yoshie H: FcgammaRlllb genotypes and smoking in periodontal disease progression among community-dwelling older adults in Japan. J Periodontol 2005, 76:250-255.

69. Yamamoto K, Kobayashi T, Grossi S, Ho AW, Genco RJ, Yoshie H, De Nardin E: Association of Fcgamma receptor lla genotype with chronic periodontitis in Caucasians. J Periodontol 2004, 75:517-522.

70. Nibali L, Parkar M, D'Aiuto F, Suvan JE, Brett PM, Griffiths GS, Rosin M, Schwahn C, Tonetti MS: Vitamin D receptor polymorphism (-1056 Taq-I) interacts with smoking for the presence and progression of periodontitis. J Clin Periodontol 2008, 35:561-567.

71. Kim JS, Park JY, Chung WY, Choi MA, Cho KS, Park KK: Polymorphisms in genes coding for enzymes metabolizing smoking-derived substances and the risk of periodontitis. J Clin Periodontol 2004, 31:959-964.

doi:10.1186/1617-9625-8-4

Cite this article as: Ojima and Hanioka: Destructive effects of smoking on molecular and genetic factors of periodontal disease. Tobacco Induced Diseases 2010 8:4.

\section{Submit your next manuscript to BioMed Central and take full advantage of:}

- Convenient online submission

- Thorough peer review

- No space constraints or color figure charges

- Immediate publication on acceptance

- Inclusion in PubMed, CAS, Scopus and Google Scholar

- Research which is freely available for redistribution

Submit your manuscript at www.biomedcentral.com/submit
C Biomed Central 